\title{
PHYSICAL AND CHEMICAL CHARACTERISTICS OF GOAT MILK POWDER WITH DIFFERENT DRYING METHODS AFTER STORAGE
}

\author{
Heni Rizqiati ${ }^{* 1)}$, Nurwantoro ${ }^{1)}$, Siti Susanti ${ }^{1)}$, Andi Febrisiantosa ${ }^{2)}$, Triana Setyawardani ${ }^{3)}$, Claradhita Ayu \\ Shauma ${ }^{1)}$ \\ 1) Fakultas Peternakan dan Pertanian, Universitas Diponegoro, Jl. Prof. Soedarto, SH. Tembalang - Semarang, \\ 50275, Indonesia \\ ${ }^{2)}$ Balai Penelitian Teknologi Bahan Alam - Lembaga Penelitian Indonesia, Jl. Yogya - Wonosari km 31,5 \\ Gading, Playen, Gunungkidul - Daerah Istimewa Yogyakarta, 55861, Indonesia \\ ${ }^{3)}$ Fakultas Peternakan, Universitas Jenderal Soedirman, Jl. Dr. Soeparno Karangwangkal - Purwokerto, 53122, \\ Indonesia \\ Email: heni.rizqi@gmail.com
}

Submitted 15 August 2020; Accepted 29 December 2020

\begin{abstract}
Processing kefir into powder form is an effort to extend shelf life, prevent contamination from unwanted bacteria, and facilitate storage. For this reason, a proper drying method is needed to produce a good quality kefir powder. There are three types of drying methods used in this study, namely drying with a cabinet dryer, freeze dryer, and spray dryer. The purpose of this study was to determine the effect of different types of drying methods on $\mathrm{pH}$ value, solubility, viscosity, total acid, and alcohol content of goat's milk kefir powder after storage for two months. This study used a completely randomized design method with different types of drying methods, namely $\mathrm{T}_{1}$ (cabinet dryer), $\mathrm{T}_{2}$ (freeze dryer), and $\mathrm{T}_{3}$ (spray dryer). The data were analyzed using Analysis of Variance (ANOVA) with a confidence level of $95 \%$ and if it had a significant effect, it was continued with the Duncan Multiple Range Test. The results showed that the different drying methods did not show any significant effect $(p>0.05)$ on the $\mathrm{pH}$ value, solubility, viscosity, total acid, and alcohol content, so it could be concluded that the three types of drying methods did not affect physical and chemical quality of kefir powder that has been stored for two months.
\end{abstract}

Keywords: Cabinet dry; freeze dry; goat's milk; powdered kefir; spray dry 


\section{INTRODUCTION}

Kefir is a fermented drink made by adding kefir grain to cow's milk, goat's milk, or buffalo's milk to form a distinctive taste (sour and alcoholic sensation) as a result of the activity of lactic acid bacteria and yeast on kefir grain (Farag et al., 2020). Kefir grains are bacterial colonies consisting of lactic acid bacteria such as Streptococcus, Lactobacillus sp, and several types of yeast that work symbiotically with other elements to form dense tissues to ferment lactose (Safitri \& Swarastuti, 2013). Kefir is beneficial for health, namely as a probiotic that can suppress the growth of bacteria that causes digestive tract diseases. The manufacture of kefir in this study uses raw materials from goat's milk, this milk was chosen because it has a higher content of lactose, protein, carbohydrates, and solids compared to cow's milk (Rachman et al., 2018). According to Moeljanto \& Wiryanta (2002), cow's milk has the following nutritional content, $3.2 \%$ protein, $3.6 \%$ fat, $4.7 \%$ lactose, and $0.7 \%$ minerals, while goat's milk contains $3.4 \%$ protein, $3.8 \%$ fat, $4.1 \%$ lactose, and $0.8 \%$ minerals.

Based on these nutritional content, it shows that the nutritional content of goat's milk is higher than cow's milk. In addition, goat's milk also has smaller fat molecules and has a short chain of fatty acids, this makes goat's milk more digestible than cow's milk (Schettino et al., 2017). Kefir has a shelf life of about $10 \mathrm{~d}$ when stored at $4^{\circ} \mathrm{C}$, because this storage can inhibit the growth of pathogenic bacteria (Setyawardani \& Sumarmono, 2015). This shows that kefir has a relatively short shelf life and should be stored at low temperatures. One of the efforts to extend shelf life, prevent

\footnotetext{
*Corresponding author:

Heni Rizqiati

Email: heni.rizqi@gmail.com

Fakultas Peternakan dan Pertanian, Universitas Diponegoro, Jl. Prof. Soedarto, SH. Tembalang Semarang, 50275, Indonesia
}

contamination from unwanted bacteria, and facilitate storage of kefir requires further processing into powder products. In principle, processing into powder products is to reduce the moisture content in the material to a certain extent so that chemical activity and microorganisms in the material can be inhibited (Imanningsih, 2013). To produce quality kefir powder, a proper drying method is needed.

There are various types of drying methods, but in this study three different drying methods were used, namely cabinet dryers, freeze dryers, and spray dryers. A cabinet dryer is a drying method using an oven in which there is a tiered shelf, equipped with a blower to disperse heat, and a thermocouple to maintain temperature (Mardiah et al., 2017). The cabinet dryer was chosen because it has several advantages, including a fast drying process that saves time, does not experience significant changes in color and appearance, and is more hygienic because the dried product is completely protected from dust, insects, birds, and rain (Chaudhary et al., 2020).

The second drying method used is the freeze dryer where the freeze dryer is one of the best drying methods for food products with the principle of eliminating the water content contained in the material as vapor by a sublimation process, but the freeze dryer also has a disadvantage, namely high production costs making it less economical (Jiang et al., 2014). The next drying method is a spray dryer. This method was chosen because it is the most common drying method used for microencapsulation of foodstuffs, it is cheap and simple, and the drying process uses a spraying method with a high drying temperature so not all

How to cite:

Rizqiati, H., Nurwantoro., Susanti, S., Febriantosa, A., Setyawardani, T., \& Shauma, C. A. (2021). Physical and chemical characteristics of goat milk powder with different drying methods after storage. Jurnal Ilmu dan Teknologi Hasil Ternak (JITEK), $16(1), 65-74$ 
ingredients are suitable for this drying method (S. H. Anwar \& Kunz, 2011). This study aims to determine the effect of different drying methods on $\mathrm{pH}$, solubility, viscosity, total acid, and alcohol content in goat's milk powder kefir after two months of storage.

\section{MATERIALS AND METHODS}

This research was conducted in March - October 2019 at the Food Chemistry and Nutrition Laboratory and Food and Agricultural Products Engineering Laboratory, Faculty of Animal Husbandry and Agriculture, Diponegoro University, Semarang and at the Balai Penelitian Teknologi Bahan Alam - Lembaga Penelitian Indonesia, Yogyakarta.

\section{Materials}

The materials that used in this study were fresh goat's milk, kefir grain, distilled water, $\mathrm{NaOH} 0.1 \mathrm{~N}$ solution, and PP solution (phenolphthalein 1\%). The equipment used is a cabinet dryer (Maksindo, MKSFDH10), freeze dryer, spray dryer (BUCHI Mini Spray Dryer B-290), grinder (Maksindo MKS-ML300), pH meter (OHAUS Starter 2100), Viscometer Ostwald (Viscometer Ostwald $5 \mathrm{ml}$ PYREX), oven (Memmert UN55), filter paper, titration device, desiccator, pycnometer and analytical balance (SHIMADZU ATY224).

\section{Method}

\section{Research Stages}

\section{The Process of Making Kefir}

Making kefir from goat's milk refers to (Kinteki et al., 2019). Kefir grain is weighed as much as $50 \mathrm{~g}$ in 1 liter of fresh goat's milk or as much as $5 \%$ to the volume of goat's milk. Fresh goat's milk is pasteurized first at a temperature of $70^{\circ} \mathrm{C}$ for $15 \mathrm{~s}$, then lowered to $30^{\circ} \mathrm{C}$. Kefir grain is then putted inside the 1 liter of goat's milk and stirred slowly until blended. Milk is then incubated at room temperature or about $20-25^{\circ} \mathrm{C}$ for $24 \mathrm{~h}$, then filtered to separate the kefir grain from the product. Liquid kefir is stored at $4{ }^{\circ} \mathrm{C}$ first before proceeding to the next process, namely the making of kefir powder.

\section{The Process of Making Kefir Powder}

Making kefir powder is done by using three different types of drying methods, namely cabinet dryers, freeze dryers, and spray dryers. Drying kefir with a cabinet dryer (Paramita et al., 2015). This is done by pouring kefir into a baking sheet then put into a cabinet dryer (Maksindo, MKS$\mathrm{FDH} 10)$ at a temperature of $50^{\circ} \mathrm{C}$ for $24 \mathrm{~h}$, then after drying the kefir is grind with a grinder and sieved to a size of 60 mesh to obtain a uniform size. Drying kefir with a freeze dryer (Yulvianti et al., 2015) done by using a freeze dryer with a $\mathrm{P}$ setting of vacuum 0.06 mbar and $\mathrm{T}$ ice condenser freezer $-45^{\circ} \mathrm{C}$, then dried for $36 \mathrm{~h}$.

Drying with a spray dryer Kefir (Pramitasari et al., 2011) is carried out by drying kefir using a spray dryer (BUCHI Mini Spray Dryer B-290) with an inlet temperature of $110^{\circ} \mathrm{C}$. The kefir powder that has been obtained is put into a ziplock plastic with food-grade silica gel in it. Then, all kefir powders from the three types of drying methods were stored at room temperature or about $20-25^{\circ} \mathrm{C}$ for two months.

\section{Procedure of Analysis pH Value Test (Azizah et al., 2012)}

Testing the $\mathrm{pH}$ value was carried out using a $\mathrm{pH}$ meter (OHAUS Starter 2100). The $\mathrm{pH}$ meter is turned on and waiting to be constant for 15-30 min. $1 \mathrm{~g}$ of powdered kefir was rehydrated with $10 \mathrm{ml}$ of distilled water. The cathode on the $\mathrm{pH}$ meter is then immersed in the sample and left for a while until the test results are shown on the display instrument.

\section{Solubility Test (AOAC, 2005)}

Solubility testing was carried out with $1 \mathrm{~g}$ of powdered kefir samples weighed (a) is dissolved with distilled water as much $20 \mathrm{ml}$ at $50^{\circ} \mathrm{C}$ temperature and filtered using 
filter paper. The filter paper is oven heated at $105^{\circ} \mathrm{C}$ for $30 \mathrm{~min}$ and weighed (b). After filtering, the filter paper was re-oven at $105^{\circ} \mathrm{C}$ until a constant weight was obtained and the sample was put into a desiccator for 15 min then weighed (c). Calculation of the solubility of powdered kefir can be calculated using the formula:

$$
\text { Solubility }=1-\left(\frac{(c-b)}{a}\right) \times 100 \%
$$

\section{Viscosity Test (Harjiyanti et al., 2013)}

Viscosity testing was carried out using a Viscometer Ostwald (Viscometer Ostwald $5 \mathrm{ml}$ PYREX). The density of water is measured first by weighing the empty pycnometer, as much as $10 \mathrm{ml}$ of distilled water is put into the pycnometer and weighed again, then the rehydrated sample is put into the pycnometer and weighed. Then, proceed with the sample that has been rehydrated and distilled water is inserted into the Ostwald pipe in turn and the water drop time is calculated until it reaches the lower tera mark using a stopwatch. Calculation of the viscosity of powdered kefir can be calculated using the formula:

Where:

$$
\begin{gathered}
\text { Viscosity }=\frac{\rho \text { sample } \times \text { t sample } \times \eta \text { water }}{\rho \text { water } \times \text { t water }} \\
\rho \text { sample }=\frac{\mathrm{m}^{\prime}-\mathrm{m}}{\mathrm{v}}
\end{gathered}
$$

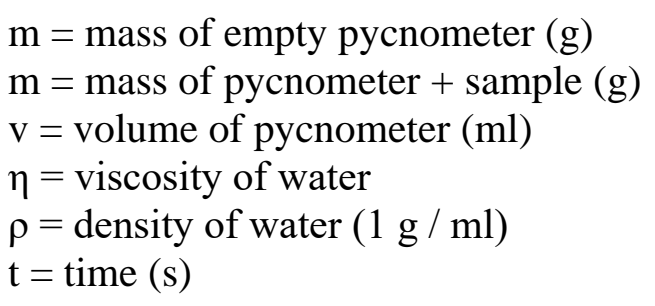

Total Acid Test (Masykur \& Kusnadi, 2015)

This test was carried out by the titration method. $1 \mathrm{~g}$ of powdered kefir is rehydrated with $10 \mathrm{ml}$ of distilled water then put into a $100 \mathrm{ml}$ volumetric flask. The sample is then added 2 drip of $1 \% \mathrm{PP}$ indicator and was titrated with $0.1 \mathrm{~N} \mathrm{NaOH}$ solution until a constant pink color was obtained. Calculation of total acid can be calculated using the formula:

$$
\text { Total Acid }(\%)=\frac{\mathrm{ml} \mathrm{NaOH} \times \mathrm{N} \mathrm{NaOH} \times \mathrm{BE} \text { Lactic Acid }(90)}{\text { Sample Weight } \times 1000} \times 100 \%
$$

\section{Alcohol Content Test (Azizah et al., 2012)}

The alcohol content test was carried out using the distillation method. A total of $100 \mathrm{ml}$ of rehydrated samples were put into a Kjeldahl flask and added with $100 \mathrm{ml}$ of distilled water, then distilled until a distillate was obtained as much as $50 \mathrm{ml}$. Weighed the empty pycnometer, pycnometer filled with distilled water, and pycnometer filled with distillate. The alcohol content of goat's milk powder kefir is obtained from the conversion of alcohol density. Calculation of the density of alcohol can be calculated using the formula:

Density of Alcohol $=\frac{(\text { Pycnometer Weight }+ \text { Distillate Weight })-\text { Empty Pycnometer Weight }}{(\text { Pycnometer Weight }+ \text { Aquadest Weight })-\text { Empty Pycnometer Weight }}$ 


\section{Research Design}

The manufacture of goat's milk powder kefir is designed using a Completely Randomized Design (CRD) with different drying methods, namely the cabinet dryer, freeze dryer, and spray dryer. The data from the test results were analyzed using Analysis of Variance (ANOVA) with a confidence level of $95 \%$ and if it had a significant effect then it was continued with the Duncan Multiple Range Test. Data analysis was performed using the SPSS application for Windows 25.0.

\section{RESULTS AND DISCUSSION}

\section{The pH value}

Based on Table 1, it can be seen that the difference in the drying method of kefir goat's milk powder that has been stored for two months does not show any significant effect ( $p>0.05)$. Powdered kefir in the three types of drying methods after being stored for two months at room temperature did not experience a significant change in $\mathrm{pH}$ value. According to Magra et al. (2012), kefir has decreased $\mathrm{pH}$ value during fermentation then the $\mathrm{pH}$ value will be constant after the 7 th $\mathrm{d}$ of fermentation, this happens because at low $\mathrm{pH}$ the activity of lactic acid bacteria decreases and yeast can inhibit the formation of lactic and acetic acids so that the kefir $\mathrm{pH}$ value remains constant and don't get more acidic. Kefir has a low $\mathrm{pH}$ value due to the activity of lactic acid bacteria which converts the sugar in milk (lactose) into lactic acid during the fermentation process (Fernandes et al., 2017). The quality requirements for kefir powder are based on the $\mathrm{pH}$ value according to research conducted by Teijeiro et al. (2018) that kefir drinks have a typical $\mathrm{pH}$ value ranging from 4 to 4.4. The $\mathrm{pH}$ value produced in powdered kefir with these three drying methods has not met the standard $\mathrm{pH}$ value in this study. Kefir, which has a lower $\mathrm{pH}$ value, increases its solubility, viscosity, total acid, and alcohol content. The $\mathrm{pH}$ value has an inverse relationship with total acid, where the more kefir acid, the lower the $\mathrm{pH}$ value and the total acid value will increase (Djali et al., 2017). Febrisiantosa et al. (2013) stated that the $\mathrm{pH}$ value is also related to the viscosity of kefir, where the lower the $\mathrm{pH}$ value and the higher the total acid value of kefir, the viscosity will increase. This is due to the activity of microorganisms in kefir, namely lactic acid bacteria and yeast.

Tabel 1. Results Analysis of $\mathrm{pH}$ Value, Solubility, Viscosity, Total Acid and Alcohol Powdered Goat's Milk Kefir After Two Months During Storage

\begin{tabular}{cccccc}
\hline Treatment & $\mathrm{pH} \mathrm{Value}^{\mathrm{ns}}$ & Solubility $(\%)^{\mathrm{ns}}$ & ${\text { Viscosity }(\mathrm{cP})^{\mathrm{ns}}}$ & ${\text { Total Acid }(\%)^{\mathrm{ns}}}$ & Alcohol $^{\mathrm{ns}}$ \\
\hline $\mathrm{T}_{1}$ & $5,15 \pm 0,41$ & $41,46 \pm 4.95$ & $1,37 \pm 0,08$ & $0,66 \pm 0,39$ & 0 \\
$\mathrm{~T}_{2}$ & $4,90 \pm 0,34$ & $41,96 \pm 6.75$ & $1,45 \pm 0,15$ & $0,60 \pm 0,35$ & 0 \\
$\mathrm{~T}_{3}$ & $4,90 \pm 0,31$ & $37,16 \pm 5.49$ & $1,46 \pm 0,19$ & $0,70 \pm 0,29$ & 0 \\
\hline
\end{tabular}

Keterangan:

Data displayed as the mean value of 7 repetitions

ns: not significant

$\mathrm{T}_{1}, \mathrm{~T}_{2}, \mathrm{~T}_{3}$ is a type of drying method, namely cabinet dryer, freeze dryer, spray dryer

\section{Solubility}

Based on Table 1, it can be seen that the difference in drying methods for kefir goat's milk powder that has been stored for two months does not show any significant effect ( $p>0.05)$. Powdered kefir that has been stored for two months at room temperature has relatively low solubility, namely around $37.16 \%$ to $41.96 \%$ because in its manufacture it does not use fillers that can increase solubility. Tontul \& Topuz (2017) states that the solubility of powder products is influenced by the use of fillers where carbohydrate-based fillers such as maltodextrin and gum arab can increase product solubility, while protein-based fillers such as soy protein isolates have low solubility. In addition, protein solubility is 
also influenced by protein denaturation due to heat treatment during drying and due to acidic conditions during fermentation.

Denatured protein due to heat treatment will change the folds of the milk protein structure so that the outer layer is hydrophobic or in other words, increases its hydrophobicity (Wijayanti et al., 2014). Wang et al. (2014) and Nalu et al. (2019) added that proteins that have high hydrophobicity have difficulty interacting with water, causing a decrease in solubility and precipitation.

Several factors can affect the solubility of powdered milk products, including the content of lactic acid in milk, heat treatment of milk, drying methods, and protein content in milk (Sharma et al., 2012). According to Sulieman et al. (2014), the requirement for a good powder product is that it has a high level of solubility when dissolved in water it will form a stable suspension and dissolve completely or form a solution. Low $\mathrm{pH}$ values and increased total acid can reduce the solubility of kefir and increase its viscosity.

\section{Viscosity}

Based on Table 1, it can be seen that the difference in drying methods for kefir goat's milk powder that has been stored for two months does not show any significant effect ( $p>0.05)$. Powdered kefir that was dried using all drying methods and then rehydrated would produce a relatively low viscosity ranging from 1.37 to $1.46 \mathrm{cP}$. This occurs because the storage temperature affects the viscosity of kefir, where storage at high temperatures produces low viscosity while frozen storage produces high viscosity (Samantha et al., 2015).

In addition, the drying process can also affect the viscosity of kefir, wherein the drying method the cabinet dryer uses a temperature of $50^{\circ} \mathrm{C}$ and the spray dryer uses an inlet temperature of $110^{\circ} \mathrm{C}$. This causes the protein contained in milk to experience denaturation due to heat. Manassero et al. (2016) argue that proteins that are subjected to high temperatures will experience denaturation, causing a decrease in viscosity. Supported by Wang et al. (2014) which states that denaturation of protein due to heat causes an increase in protein hydrophobicity which causes the protein to become insoluble.

Another factor that causes a low viscosity on kefir is that no filler is added during the manufacturing process. Yana \& Kusnadi (2015) states that the more filler concentrations are added, the viscosity will increase. The $\mathrm{pH}$ value can also affect the solubility of milk protein (casein), where the $\mathrm{pH}$ value that has reached the casein isoelectric point will cause the casein aggregate to become weak so that it can affect the viscosity of kefir (Purbasari et al., 2014).

\section{Total Acid}

Based on Table 1, it can be seen that the difference in the drying method of goat's milk powder kefir that has been stored for two months does not show any significant effect ( $p>0.05)$. Kefir powder in the three types of drying methods after being stored for two months at room temperature did not experience a significant change in total acid.

The quality requirement for kefir based on total acid according to World Health Organization and Food and Agriculture Organization of the United States (2011) regarding the standard of fermented drinks is a minimum of $0.6 \%$. The total acid produced in powdered kefir by these three drying methods has met the total kefir acid standard that has been set.

The total acid produced in kefir is due to the activity of lactic acid bacteria with the help of the $\beta$-D-galactosidase enzyme to convert glucose into lactic acid which can lower $\mathrm{pH}$ and increase acidity (Rossi et al., 2016). Nagovska et al. (2018) stated that the longer the storage, the higher the total acid formed, this is due to an increase in the growth of lactic acid bacteria so that more lactic acid is produced. The higher the total acid, the $\mathrm{pH}$ value and solubility of milk protein will decrease and the viscosity increases. 


\section{Alcohol Content}

Based on Table 1, it can be seen that the difference in the drying method of kefir goat's milk powder that has been stored for two months does not show any significant effect ( $p>0.05)$. This happens because the powdered kefir before storage also produces zero alcohol content. The zero or negative alcohol content in powdered kefir with the three different types of drying methods is due to the high temperature in the manufacture of powder kefir, where the method cabinet dryer uses a temperature of $50^{\circ} \mathrm{C}$ and the spray dryer uses an inlet temperature of $110^{\circ} \mathrm{C}$. The heating process with high temperatures can inhibit the fermentation process of microorganisms so that the alcohol content produced will also decrease (Mardiyah, 2017). Likewise, in the method freeze dryer, this drying uses low temperatures so that the activity of microorganisms can be inhibited (Ayuti et al., 2016). Sinurat et al. (2019) stated that alcohol production in kefir is influenced by $\mathrm{pH}$, total acid content, fermentation time, type of substrate, temperature, and the microorganisms used. The lower the $\mathrm{pH}$ value and the higher the total acid produced, the higher the activity of microorganisms, so that the amount of alcohol produced will also increase. The alcohol content in kefir is due to the activity of Saccharomyces cerevisiae in converting simple sugars in this case lactose into alcohol and $\mathrm{CO}_{2}$ gas (Anwar et al., 2012).

\section{CONCLUSION}

Based on the results obtained, it can be concluded that the differences in drying methods do not affect the $\mathrm{pH}$, solubility, viscosity, total acid, and alcohol content of kefir goat's milk powder that has been stored for two months at room temperature.

\section{ACKNOWLEDGMENTS}

Thank you to the Directorate of Research and Community Service, Deputy for Strengthening Research and
Development, the Ministry of Research and Technology/ National research Innovation Agency for providing funding through the Higher Education Leading Basic Research, with the Activity Implementation Agreement No. 257-45/ UN7.P4.3/ PP/ 2019 dated 1 April 2019.

\section{REFERENCES}

Anwar, M. S., Al-Barrii, A. N., \& Legowo, A. M. (2012). Volume gas, pH, dan kadar alkohol pada proses produksi bioetanol dari acid whey yang difermentasi oleh Saccharomyces cerevisiae. Jurnal Aplikasi Teknologi Pangan, 1(4), 133-136.

Anwar, S. H., \& Kunz, B. (2011). The influence of drying methods on the stabilization of fish oil microcapsules: Comparison of spray granulation, spray drying, and freeze drying. Journal of Food Engineering. https://doi.org/10.1016/j.jfoodeng.20 11.02 .047

AOAC. (2005). Official Methods of Analysis of AOAC International. In Association of Official Analysis Chemists International.

Ayuti, S. R., Nurliana, N., Yurliasni, Y., Sugito, S., \& Darmawi, D. (2016). Dinamika pertumbuhan Lactobacillus casei dan karakteristik susu fermentasi berdasarkan suhu dan lama penyimpanan. Jurnal Agripet. https:// doi.org/10.17969/agripet.v16i1.3476

Azizah, N., Al-Barrii, A. N., \& Mulyani, S. (2012). Pengaruh lama fermentasi terhadap kadar alkohol, $\mathrm{pH}$, dan produksi gas pada proses fermentasi bioetanol dari whey dengan substitusi kulit nanas. Jurnal Aplikasi Teknologi Pangan, 3(1), 72-77.

Chaudhary, V., Kumar, V., Singh, B. R., Singh, J., Chauhan, N., \& Kumar, P. (2020). Drying characteristics of Bael pulp using different drying methods and different varieties. International Journal of Agricultural Engineering, 13(1), 19-30. https://doi.org/10.157 
40/HAS/IJAE/13.1/19-30

Djali, M., Marta, H., \& Harnah, S. (2017). Characterics of freeze dried jack bean yogurt powder with maltodextrin as coating material. Jurnal Penelitian Pascapanen Pertanian. https://doi.org/ 10.21082/jpasca.v13n1.2016.28-35

Farag, M. A., Jomaa, S. A., El-wahed, A. A., \& El-seedi, H. R. (2020). The many faces of kefir fermented dairy products: Quality characteristics, flavour chemistry, nutritional value, health benefits, and safety. In Nutrients. https://doi.org/10.3390/nu1 2020346

Febrisiantosa, A., Priyo Purwanto, B., Isnafia Arief, I., \& Widyastuti, Y. (2013). Karakteristik fisik, kimia, mikrobiologi whey kefir dan aktivitasnya terhadap penghambatan Angiotensin Converting Enzyme (ACE). Jurnal Teknologi Dan Industri Pangan. https://doi.org/10.6066/jtip.2 013.24.2.147

Fernandes, M. S., Lima, F. S., Rodrigues, D., Handa, C., Guelfi, M., Garcia, S., \& Ida, E. I. (2017). Evaluation of the isoflavone and total phenolic contents of kefir-fermented soymilk storage and after the in vitro digestive system simulation. Food Chemistry, 229, 373-380. https://doi.org/10.1016/j.fo odchem.2017.02.095

Harjiyanti, M. D., Pramono, Y. B., \& Mulyani, S. (2013). Total asam, visikositas, dan kesukaan pada yoghurt drink dengan sari buah mangga (Mangifera Indica) sebagai perisa alami. Jurnal Aplikasi Teknologi Pangan, 2(2), 104-107.

Imanningsih, N. (2013). Pengaruh suhu ruang penyimpanan terhadap kualitas susu. Agrointek.

Jiang, H., Zhang, M., Mujumdar, A. S., \& Lim, R. X. (2014). Comparison of drying characteristic and uniformity of banana cubes dried by pulse-spouted microwave vacuum drying, freeze drying and microwave freeze drying. Journal of the Science of Food and
Agriculture. https://doi.org/10.1002/js fa.6501

Kinteki, G., Rizqiati, H., \& Hintono, A. (2019). Pengaruh lama fermentasi kefir susu kambing terhadap mutu hedonik, total bakteri asam laktat (BAL), total khamir, dan $\mathrm{pH}$. Jurnal Aplikasi Teknologi Pangan, 3(1), 42-50. https://doi.org/10.14710/jtp.3.1.42-50

Magra, T. I., Antoniou, K. D., \& Psomas, E. I. (2012). Effect of milk fat, kefir grain inoculum and storage time on the flow properties and microbiological characteristics of kefir. Journal of Texture Studies. https://doi.org/10. 1111/j.1745-4603.2011.00343.x

Manassero, C. A., Vaudagna, S. R., Sancho, A. M., Añón, M. C., \& Speroni, F. (2016). Combined high hydrostatic pressure and thermal treatments fully inactivate trypsin inhibitors and lipoxygenase and improve protein solubility and physical stability of calcium-added soymilk. Innovative Food Science and Emerging Technologies. https://doi.org/10.1016/ j.ifset.2016.04.005

Mardiah, M., Novidahlia, N., \& Mashudi, M. (2017). Penentuan Metode Pengeringan (Cabinet Dryer Dan Fluidized Bed Dryer) Terhadap Komponen Dan Kapasitas Antioksidan Pada Rosela Kering (Hibiscus sabdariffa L). Jurnal Pertanian. https://doi.org/10.30997/ JP.V3I2.603

Mardiyah, S. (2017). Pengaruh Lama Pemanasan Terhadap Kadar Alkohol Pada Nira Siwalan (Borassus flabellifer). The Journal of Muhammadiyah Medical Laboratory Technologist. https://doi.org/10.3065 1/jmlt.v1i1.977

Masykur, A., \& Kusnadi, J. (2015). Karakteristik Kimia Dan Mikrobiologi Yoghurt Bubuk Kacang Tunggak (Vigna unguiculata L.) Metode Pengeringan Beku (Kajian Penambahan Starter Dan Dekstrin). Jurnal Pangan Dan Agroindustri. 
Moeljanto, R. D., \& Wiryanta, B. T. W. (2002). Khasiat \& manfaat susu kambing: susu terbaik dari hewan Ruminansia. In agro media.

Nagovska, V. O., Hachak, Y. R., Bilyk, O. Y., Gutyj, B. V., Slyvka, N. B., \& Mikhailytska, O. R. (2018). Influence of thistle grist on organoleptic, physico-chemical and microbiological parameters of kefir. Scientific Messenger of LNU of Veterinary Medicine and Biotechnologies. https://doi.org/10.15421/nvlvet8530

Nalu, A. R., Yudiono, K., \& Susilowati, S. (2019). Pengaruh penambahan starter yogurt dan susu skim terhadap kualitas yogurt susu kacang hijau (Vigna Radiata L). Jurnal BisTek PERTANIAN: Agribisnis Dan Teknologi Hasil Pertanian, 6(1). https://doi.org/10.37832/bistek.v6i01.4

Paramita, I. A. M. ., Mulyani, S., \& Hartiati, A. (2015). Pengaruh konsentrasi maltodekstrin dan suhu pengeringan terhadap karakteristik bubuk minuman sinom. Jurnal Rekayasa Dan Manajemen Agroindustri, 3(2), 58-68.

Pramitasari, D., Anandhito, R. B. K., \& Fauza, G. (2011). Penambahan ekstrak jahe dalam pembuatan susu kedelai bubuk instan dengan metode spray drying: komposisi kimia, sifat sensoris, dan aktivitas antioksidan. Biofarmasi Journal of Natural Product Biochemistry. https://doi.org/ 10.13057/biofar/f090104

Purbasari, A., Pramono, Y. B., \& Abduh, S. B. M. (2014). Nilai pH, kekentalan, citarasa asam, dan kesukaan pada susu fermentasi dengan perisa alami jambu air (Syzygium sp). Jurnal Aplikasi Teknologi Pangan.

Rachman, A., Taufik, E., \& Arief, I. I. (2018). Karakteristik yoghurt probiotik rosella berbahan baku susu kambing dan susu sapi selama penyimpanan suhu ruang. Jurnal Ilmu Produksi Dan Teknologi Hasil Peternakan. https://doi.org/10.29244/ jipthp.6.2.73-80

Rossi, E., Hamzah, F., \& Febriyani, F. (2016). Perbandingan susu kambing dan susu kedelai dalam pembuatan kefir. Jurnal Peternakan Indonesia. https://doi.org/10.25077/jpi.18.1.1320.2016

Safitri, M. F., \& Swarastuti, A. (2013). Kualitas kefir berdasarkan konsentrasi kefir grain. Jurnal Aplikasi Teknologi Pangan. https://doi.org/10.17728/JA TP.V2I2.124

Samantha, S. C., Bruna, A. S. M., Adriana, R. M., Fabio, B., Sandro, A. R., \& Aline, R. C. A. (2015). Drying by spray drying in the food industry: Micro-encapsulation, process parameters and main carriers used. African Journal of Food Science. https://doi.org/10.5897/ajfs2015.1279

Schettino, B., Vega, S., Gutiérrez, R., Escobar, A., Romero, J., Domínguez, E., \& González-Ronquillo, M. (2017). Fatty acid profile of goat milk in diets supplemented with chia seed (Salvia hispanica L.). Journal of Dairy Science. https://doi.org/10.3168/jds.2 017-12785

Setyawardani, T., \& Sumarmono, J. (2015). Chemical and microbiological characteristics of goat milk kefir during storage under different temperatures. Journal of the Indonesian Tropical Animal Agriculture. https://doi.org/10.14710/ jitaa.40.3.183-188

Sharma, A., Jana, A. H., \& Chavan, R. S. (2012). Functionality of Milk Powders and Milk-Based Powders for End Use Applications-A Review. In Comprehensive Reviews in Food Science and Food Safety. https://doi. org/10.1111/j.1541-4337.2012.00199.x

Sinurat, R. La, Ekowati, C. N., Sumardi, S., \& Farisi, S. (2019). Karakteristik kefir susu sapi dengan inokulum ragi tape. Jurnal Ilmiah Peternakan Terpadu. https://doi.org/10.23960/jipt.v6i2.p11 $1-116$

Sulieman, A. M. E., Elamin, O. M., 
Elkhalifa, E. A., \& Laleye, L. (2014). Comparison of physicochemical properties of spray-dried camel's milk and cow's milk powder. International Journal of Food Science and Nutrition Engineering. https://doi.org/10.5923/ j.food.20140401.03

Teijeiro, M., Pérez, P. F., De Antoni, G. L., \& Golowczyc, M. A. (2018). Suitability of kefir powder production using spray drying. Food Research International. https://doi.org/10.1016/ j.foodres.2018.06.023

Tontul, I., \& Topuz, A. (2017). Spraydrying of fruit and vegetable juices: Effect of drying conditions on the product yield and physical properties. In Trends in Food Science and Technology. https://doi.org/10.1016/ j.tifs.2017.03.009

Wang, Z., Li, Y., Jiang, L., Qi, B., \& Zhou, L. (2014). Relationship between secondary structure and surface hydrophobicity of soybean protein isolate subjected to heat treatment. Journal of Chemistry. https://doi. org/10.1155/2014/475389

Wijayanti, H. B., Bansal, N., \& Deeth, H. C. (2014). Stability of whey proteins during thermal processing: a review. Comprehensive Reviews in Food Science and Food Safety. https://doi. org/10.1111/1541-4337.12105

World Health Organization and Food and Agriculture Organization of the United States. (2011). Codex Standard for Fermented Milks - CODEX STAN-243-2003. Codex Alimentarius.

Yana, M. F., \& Kusnadi, J. (2015). Pembuatan yogurt berbasis kacang tunggak (Vigna Unguiculata) dengan metode freeze drying (kajian jenis dan konsentrasi bahan pengisi). Jurnal Pangan Dan Agroindustri.

Yulvianti, M., Ernayati, W., Tarsono, \& Alfian, M. R. (2015). Pemanfaatan ampas kelapa sebagai bahan baku tepung kelapa tinggi serat dengan metode freeze drying. Jurnal Integrasi Proses, 5(2), 101-107. https://doi.org/ http://dx.doi.org/10.36055/jip.v5i2.246 